\title{
STUDI PERBANDINGAN DUA KELOMPOK UMUR TERHADAP MULA KERJA DAN MASA KERJA ANESTETIKA LOKALPADA KASUS PENCABUTAN GIGI MOLAR I ATAU MOLAR II ATAS
}

\author{
Mahmud Kholifa \\ Fakultas Kedokteran Universitas Muhammadiyah Surakarta \\ Prodi Kedokteran Gigi Fakultas Kedokteran Universitas Muhammadiyah Surakarta \\ Correspondence to : Drg. Mahmud Kholifa \\ Email : Mahmudkholifa@yahoo.com
}

\begin{abstract}
Effect of infiltration due to the action of anesthesiasubstance on terminal nerve fibers maxillary molars the anesthesiafluid flow through the bone viahavers channels.This study is a quasi-experimental studies (clinical trials), which aims to determine the difference of onset and durationLidocaine between age groups 15-24 years age group 25-34 years in the case of extraction a molar tooth I or II maxilla conducted on patients who came to the Polyclinic FKG UGM, Yogyakarta. The number of samples obtained was 34 samples divided into two groups, Group I were patients with 15-24 years of age or younger, group II is patients aged 25-34 years or older. The data obtained areonset and duration of the age group 15-24 years compared with onset and duration of Lidocaine in the age group 25-34 years. The data obtained were analyzed by t-test with significance level $(p<0.05)$. The results of this study indicate that there are no significant differences between the onsetLidocaine in the age group 15-24 years with onset on the Lidocaine group 25-34 years. There is also a non-significant difference between Lidocaineduration in the group aged 15 - 24 years with a duration of Lidocaine on the group 25-34 years at $p$ $<0.05$. The mean - median onsetLidocaine in the age group 15-24 years was 60.3 seconds with a range between 22-95 seconds while the onset on the Lidocaine group 25-34 years was 55.5 seconds with a range between 14-111 seconds. The mean - average durationLidocaine in the age group 15-24 years was 162.59 minutes with a range between 120-195 minutes while the duration of Lidocaine on the group 25-34 years was 184.41 with a range between 120-330 minutes.
\end{abstract}

Keywords :onset, duration ,age group, molar tooth, local anesthesia

\section{PENDAHULUAN}

Sebelummelakukan pencabutan gigiterlebih dahulu menganestesi saraf yang menginervasi gigi tersebut. Thoma (1969) mengatakan pada anestesi infiltrasi cairan diinjeksikan sedekat mungkin dengan tulang, sehingga pada bagianbagian khusus dari tulang rahang cairan anestesi akan menembus tulang mengalir melalui saluran havers dan cairan akan mempengaruhi saraf-saraf yang menuju gigi sebelum memasuki foramen apikal dan jaringan periodontal. Pada anak-anak dan orang muda dengan tulang yang masih tipis, metode ini biasanya lebih berhasil daripada orang tua atau pasien dengan tulang yang tebal, karena disini saluran havers masih banyak dan lebar.

Pada rahang atas, gigi-gigi incisivus dan premolar sangat mudah dianestesi. Gigi-gigi canius dan molar ketiga juga mudah dianestesi, tetapi sukar pada gigi - gigi molar pertama dan kedua karena adanya processus zygomaticus yang memanjang ke bawah ke tepi alveolar, menambah ketebalan tulang pada sisi bukal (Thoma, 1969).

Thoma (1969) mengatakan bahwa pada anak-anak dan orang muda dengan tulang yang masih tipis saluran havers masih banyak dan lebar sedang pada orang tua dengan tulang yang tebal merupakan kebalikannya. Sedangkan menurut Jungueira dan Carneiro (1977) mengatakan kombinasi sintesa dan kerusakan tulang tidak hanya terjadi di dalam tulang yang sedang tumbuh tetapi juga terjadi selama kehidupan dewasa. Selama pertumbuhan dan bahkan pada tulang orang dewasa selalu ada kerusakan dan pembentukan kembali sistim havers sehingga sering terlihat sistim havers dengan hanya beberapa lamela saja 
dan suatu saluran havers yang besar.

Lignokain mampu mengurangi rasa nyeri dengan cara menghalangi transmisi atau penghantaran impuls, tanpa menyebabkan iritasi, kerusakan jaringan ataupun efek sistematik. Lignokain mempunyai mula kerja yang cepat dan masa kerja yang panjang dengan cara penambahan vasokonstriktor.

Lidokain pertama kali diperkenalkan pada tahun 1948 dan merupakan salah satu anestetika lokal yang paling banyak digunakan. Lidokain menyebabkan pati rasa lokal lebih cepat, lebih kuat, lebih lama masa kerjanya, dan lebih luas daerah anestesinya dari pada prokain dengan konsentrasi yang sama. Dari keterangan di atas maka salah satu obat yang memenuhi syarat-syarat tersebut adalah Lignokain atau Lidokain.

Bennet (1974) menyatakan ada beberapa faktor yang perlu dipertimbangkan dalam pemilihan metode injeksi: Area yang akan dianestesi, kedalaman yang dikehendaki, durasi anestesi, adanya infeksi, umur pasien, kondisi pasien, hemostasis bila diperlukan. Umur pasien selalu dipakai untuk pertimbangan. Pada individu-individu tua tulangnya mungkin padat dan sukar ditembus. Dengan kata lain, anak muda mempunyai reaksi yang berlawanan yaitu area teranestesi akan lebih luas dan terasa lebih tidak nyaman.

Dari uraian di atas dapat dilihat bahwa ada yang berpendapat jumlah dan besar saluran havers antara orang muda dengan orang tua itu sama, tetapi ada yang mengatakan berbeda. Maka timbul suatu permasalahan yaitu apakah ada perbedaan antara orang muda dan orang tua terhadap mula kerja dan masa kerja anestesi lokal dengan anestesi infiltrasi pada rahang atas.

Penelitian ini bertujuan untuk mengetahui perbedaan mula kerja dan masa kerja anestesi lokal pada orang muda dan orang tua sehingga bisa bermanfaat sebagai salah satu pertimbangan bagi dokter gigi dalam memperhitungkan waktu yang diperlukan dalam suatu tindakan pencabutan pada orang muda dan orang tua.

\section{METODE}

Penelitian ini bersifat uji klinik. Variabel pengaruh: usia pasien, variabel terpengaruh: mula kerja dan masa kerja anestetika lokal. Variabel terkendali: keadaan umum pasien, yaitu berdasarkan anamnesis pasien dinyatakan sehat tidak menderita penyakit sistemik, termasuk juga tidak adanya infeksi lokal pada regio molar satu dan molar duarahang atas, pasien adalah orang yang diindikasikan untuk pencabutan gigi molar satu atau dua atas, kiri atau kanan, dan sudah pernah mengalami pencabutan dengan anestetika lokal, pasien tidak minum anelgetika minimal 24 jam sebelum pencabutan gigi dan lima jam setelah pencabutan gigi, usia dibagi menjadi dua kelompok, kelompok I usia 15-24 tahun sedangkan kelompok II usia 25-34 tahun. Variabel tak terkendali: suku bangsa, derajat keasaman jaringan mulut, persepsi sakit obyek penelitian dan kejiwaan.

Bahan penelitian adalah anestetika lokal Lidokain $2 \mathrm{ml}$ (Paphros), analgetika, antibiotika. Alat penelitian berupa spuit injeksi $2,5 \mathrm{ml}$ sekali pakai, alat diagnostik: sonde, ekskavator, kaca mulut dan pinset, tang ekstraksi molar rahang atas, alat pencatat waktu.

Jalannya penelitian dilakukan di klinik bedah mulut, FKG, Universitas Gadjah Mada, Yogyakarta. Sampel diseleksi dari pasien yang memenuhi syarat. Pasien diminta mengisi formulir persetujuan untuk dilakukan percobaan klinis tentang pengaruh anestetika lokal pada usia muda dan usia tua, dilakukan pengukuran tekanan darah, selanjutnya pasien siap dilakukan penyuntikan. Cara anestesi nervus alveolaris superior posterior : persiapan membrana mukosa untuk injeksi, pertama jaringan harus kering, selanjutnya larutan antiseptik atau anestesi topikal yang mengandung antiseptik diaplikasikan pada area tersebut, pasien tidak diijinkan menutup mulut sampai injeksi dilakukan. Nervus alveolaris superior posterior dianestesi dengan metode subperiosteal sehingga larutan anestesi memancar menembus tulang. Titik suntik pada lipatan mucobukal atas gigi molar ke dua. Jarum dimajukan ke arah atas distal kemudian larutan dideponir diatas apek dari akar-akar gigi molar tiga, dalam injeksi ini yang teranestesi adalah molar tiga, molar dua dan akar-akar distal dan palatal molar pertama. Untuk melengkapi anestesi pada molar pertama, dilakukan injeksi subperiosteal diatas apek dari akar premolar kedua. Untuk esktraksi dan bedah periodontal, juga dilakukan injeksi pada nervus palatina anterior. Cara anestesi nervus palatina anterior : alat suntik diarahkan berhadapan dengan sudut mulut tepat disebelah mesial titik pada garis khayal yang membagi dua sama dari gingiva 
membatasi molar tiga atas sepanjang akar palatinal ke median line. Nervus palatina anterior keluar dari foramen palatina posterior, jarum jangan sampai masuk kedalam foramen, karena larutan anestesi yang berlebihan dalam lubang akan menyebabkan anestesi mengenai nervus palatinamedial sehingga menimbulkan anestesi pada langit-langit lunak yang akan mengakibatkan muntah. Injeksi ini akan menganestesi mucoperiosteum pada palatum dari tuberositas ke regio premolar dari median line ke puncak gingiva pada sisi yang diinjeksi, selanjutnya diobservasi timbulnya pati rasa pada mukosa bukal dan palatal. Mula kerja dihitung dari saat selesai penyuntikan sampai ada patirasa, kemudian gigi dicabut. Masa kerja dihitung sejak pati rasa (rasa tebal) terjadi sampai hilang rasa tersebut. Pasca pencabutan, pasien diberi instruksi untuk tidak minum obat setelah kurang lebih lima jam dari saat pencabutan. Penyuntikan obat anestetika lokal dilakukan oleh satu orang operator. Data yang diperoleh dianalisis dengan uji t dengan rumusan hipotesis Ho : $\mathrm{u} 1 \geq \mathrm{u} 2$; HA $: \mathrm{u} 1<\mathrm{u} 2$ dan Ho : $\mathrm{u} 1 \leq \mathrm{u} 2 ; \mathrm{HA}: \mathrm{u} 1>\mathrm{u} 2$ dengan tingkat signifikasi 0,05 .

\section{HASIL DAN PEMBAHASAN}

Data-data yang diperoleh dari penelitian ini yaitu mula kerja dari kedua kelompok usia yang dapat dilihat pada tabel 1 dibawah ini:

Tabel 1. Hasil pengamatan mula kerja (onset) dua kelompok umur pada pencabutan gigi molar satu atau molar dua atas.

\begin{tabular}{ccc}
\hline \multirow{2}{*}{ No. } & \multicolumn{2}{c}{ Mula kerja obat (dalam detik) } \\
\cline { 2 - 3 } & Umur $15-24$ tahun & Umur $25-34$ tahun \\
\hline 1 & 50 & 111 \\
2 & 45 & 94 \\
3 & 73 & 41 \\
4 & 75 & 46 \\
5 & 70 & 67 \\
6 & 25 & 67 \\
7 & 40 & 27 \\
8 & 57 & 51 \\
9 & 88 & 47 \\
10 & 22 & 63 \\
11 & 59 & 34 \\
12 & 35 & 53 \\
13 & 85 & 57 \\
14 & 95 & \\
\hline
\end{tabular}

\begin{tabular}{lll}
\hline 15 & 86 & 14 \\
16 & 47 & 69 \\
17 & 73 & 41 \\
\hline
\end{tabular}

Dari data mula kerja Lidokain antara dua kelompok umur seperti yang terterap ada tabel 1 , dengan uji-t diperoleh $t$ hitung: 0,61 sedangkan $\mathrm{t}$ tabel pada df : 32 dengan derajat signifikasi ( $p$ $<0,05$ ) yaitu 2,040 . Hasil tersebut menunjukkan t hitung lebih besar daripada $t$ tabel, sehingga Ho diterima, yang berarti terdapat perbedaan yang tidak bermakna antara kelompok umur 1524 tahun dengan kelompok umur 25-34 tahun terhadap mula kerja Lidokain.

Data dari hasil pengamatan dua kelompok umur terhadap masa kerja Lidokain dapat dilihat pada tabel 2 berikut:

Tabel 2. Data masa kerja Lidokain terhadap dua kelompok umur pada pencabutan molar satu atau molar dua atas

\begin{tabular}{ccc}
\hline \multirow{2}{*}{ No. } & \multicolumn{2}{c}{ Mula kerja obat (dalam menit) } \\
\cline { 2 - 3 } & Umur $15-24$ tahun & Umur $25-34$ tahun \\
\hline 1 & 130 & 330 \\
2 & 190 & 125 \\
3 & 120 & 120 \\
4 & 175 & 205 \\
5 & 195 & 155 \\
6 & 150 & 120 \\
7 & 155 & 215 \\
8 & 170 & 145 \\
9 & 195 & 225 \\
10 & 144 & 190 \\
11 & 165 & 175 \\
12 & 155 & 195 \\
13 & 135 & 185 \\
14 & 185 & 185 \\
15 & 135 & 135 \\
16 & 190 & 185 \\
17 & 175 &
\end{tabular}

Dari data masa kerja kerja Lidokain antara dua kelompok umur seperti yang tertera pada tabel 2, dengan uji-t diperoleh thitung : - 1,53 sedangkan $\mathrm{t}$ tabel pada df : 32 dengan derajat signifikasi $(\mathrm{p}<$ 0,05 ) yaitu 2,040. Hasil tersebut menunjukkan $t$ hitung lebih kecil daripada $\mathrm{t}$ tabel, sehingga Ho diterima, yang berarti terdapat perbedaan yang tidak bermakna antara kelompok umur terhadap masakerja Lidokain.

Dari tabel 1 dan tabel 2, dapat dilihat 
bahwa rata-rata mula kerja (onset) Lidokain pada kelompok umur 15-24 tahun adalah 60,3 detik, dan rata-rata mula kerja Lidokain pada kelompok umur 25-34 tahun adalah 55,5 detik. Secara statistic dengan derajat signifikasi $(\mathrm{p}<0,05)$, ternyata terdapat perbedaan yang tidak bermakna antara mula kerja Lidokain pada kelompok umur 25-34 tahun.

Rata-rata masa kerja Lidokain pada kelompok umur 15-24 tahun adalah 162,59 menit, sedangkan masa kerja Lidokain pada kelompok umur 25-34 tahun adalah 184,4 menit dan secara statistic dengan derajat signifikasi $(p<0,05)$, ternyata terdapat perbedaan yang tidak bermakna.

Dari penelusuran pustaka, beberapa peneliti berpendapat bahwa jumlah dan besar saluran havers pada orang muda lebih banyak dan lebar daripada orang tua, walaupun ada juga yang mengatakan sama, baik pada orang muda maupun orang tua. Pada penelitian ini ternyata didapatkan hasil bahwa tidak ada perbedaan yang bermakna antara orang muda dan orang tua terhadap mula kerja dan masa kerjaan estesi lokal dengan anestesi infiltrasi pada rahang atas.

Anestesi infiltrasi lebih berhasil pada processus alveolaris yang mempunyai saluran havers banyak dan lebar. Jungueira dan Carneiro (1980) mengatakan bahwa selama pertumbuhan dan bahkan pada tulang orang dewasa selalu ada kerusakan dan pembentukan kembali system havers sehingga sering terlihat system havers dengan hanya beberapa lamella saja dan suatu saluran havers yang besar. Dengan kata lain jumlah dan besar saluran havers pada orang muda dan orang tua sama, sehingga keberhasilan anestesi infiltrasi pada orang muda dan orang tua juga sama.

Hasil penelitian ini ternyata tidak sesuai dengan hipotesis yang diajukan yang menyatakan bahwa ada perbedaan dua kelompok umur terhadap mula kerja dan masa kerja anestesi lokal. Pada penelitian ini tidak dibedakan antara molar pertama dan molar kedua, karena menurut Thoma (1969) lapisan kortek paling tebal terletak pada region molar satu dan molar dua rahang atas karena adanya processus zygomaticus yang memanjang ke bawah ke tepi alveolar, sehingga menambah ketebalan tulang. Tidak dikatakan adanya perbedaan ketebalan lapisan korteks antara molar pertama dan molar kedua. Juga tidak dibedakan antara laki-laki dan perempuan, karena menurut Mitchel dan Peterson (1954) kecepatan proses penulangan dan pertumbuhan berbeda antara perempuan dan laki-laki pada usia dibawah 25 tahun. Perbedaan kekompaan tulang dan pertumbuhan antara pasien yang berusia di bawah 25 tahun atau orang muda serta pasien usia 25 tahun dan diatas 25 tahun atau orang tua tidak dipengaruhi oleh jenis kelamin.

Perbedaan yang tidak bermakna antara mula kerja dan masa kerja anestesi local terhadap dua kelompok umur mungkin juga disebabkan karena penelitian ini mempunyai keterbatasan yaitu, terdapat faktor-faktor yang tidak biasa dikendalikan antara lain: tiap orang mempunyai persepsi rasa sakit yang berbeda sehingga menimbulkan subyektifitas pada pengakuan pasien kapan pati rasa terjadi setelah penyuntikan dan kapan rasa tebal hilang setelah pencabutan.

\section{SIMPULAN}

Dari hasil penelitian ini dapat disimpulkan bahwa ada perbedaan yang tidak bermakna antara dua kelompok umur terhadap mula kerja dan masa kerja anestesi lokal.

\section{SARAN}

Dalam penelitian ini masih terdapat faktorfaktor yang tidak bisa dikendalikan terutama adanya persepsi rasa sakit yang berbeda dalam menentukan kapan pati rasa terjadi setelah penyuntikan dan kapan rasa tebal hilang setelah pencabutan sehingga menimbulkan subyektifitas terhadap data yang diperoleh sehingga perlu di rumuskan cara yang lebih terkendali untuk mendapatkan data yang lebih obyektif.

\section{DAFTAR PUSTAKA}

Bennet. C. R., 1974, Mechanism Local Anesthesi in Dental Practise, 4th ed., The C. V. Mosby Co., St Louis, p. $61-62,116$.

Jungueira, L. C., Carneiro, J., 1977, Basic Histology, $2^{\text {nd }}$ ed., Lange Medical Publications, USA., p. $122-126$.

Mitchel, G. A. G., Peterson, E. L., 1954 Basic Anatomy, E. \& S. Livingstone L. T. D., Edinburg and London, p. $46-47$.

Peterson, S., 1977, Clinical Dental Hygiene, $4^{\text {th }}$ ed., The C. V. Mosby Co., St. Louis, p. $81-83$.

Thoma, K. H., 1969, Oral Surgery, $5^{\text {th }}$ ed., The C. V. Mosby Company, St. Louis, p. 221 $222,228$. 